\title{
MR APPLICATION IN GYNECOLOGICAL MALIGNANCIES: OVARIAN LESIONS
}

\author{
Professor Bijan Bijan
}

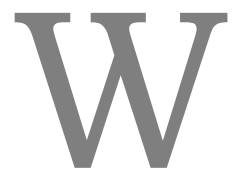

hich methods are applicable in ovarian lesions diagnostics? What are the advantages and disadvantages of US, MSCT and PET/CT? What are the advantages of MR diagnostics? What MR protocol is applicable and which recommendations should be used while performing MR of ovarian lesions? Why DWI/ADC shold be used and what is the diagnostic value? Current master class gives the answer to these and other questions.

Keywords: MSCT, MRI, PET/CT, DWI, ADC, adenocarcinoma, clear cell carcinoma, endometrioid carcinoma, poorly differentiated carcinoma, peritoneal implant, endometrioma, mucinous cystadenoma, serous cystadenoma, teratoma, Brenner Tumor.

\section{ПРИМЕНЕНИЕ МРТ ПРИ ЗАОКАЧЕСТВЕННЫХ ОБРАЗОВАНИЯХ ЯИЧНИКОВ}

\author{
Продрессор БиАжан БиАжан
}

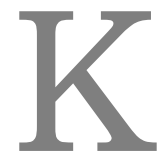

акие методы применяются дмя диагностики заболеваний яичников? В чем преимущество и недостатки УЗИ, МСКТ и ПЭТ/КТ? В чем заключается преимущество МР-диагностики? Какой протокол МР-исследования целесообразно использовать и каким рекомендациям необходимо следовать при МР-диагностике новообразований яичников? Почему необходимо использовать DWI/ADC и какова диагностическая ценность? На эти и другие вопросы дает ответ сегодняшний мастер-класс.

КАючевые слова: MCKT, MPT, ПЭТ/KT, DWI, ADC, аденокарцинома, светлоклеточный рак, эндометриоидная аденокарцинома, низкодифференцированная карцинома, имплантационные метастазы брюшины, эндометриоидная киста яичника, муцинозная цистаденома, цистаденома, тератома, опухоль Бреннера. 


\title{
А^я просмотра мастер-к^асса перейАите на сайт:
}

https://rejr.ru/twenty-fourth_nomer/master-class.html

\author{
Bijan Bijan, MD, MBA
}

Sutter imaging - SMG

Visit. Clin. Professor of Radioligy \& Nuclear Medicine (WOS)

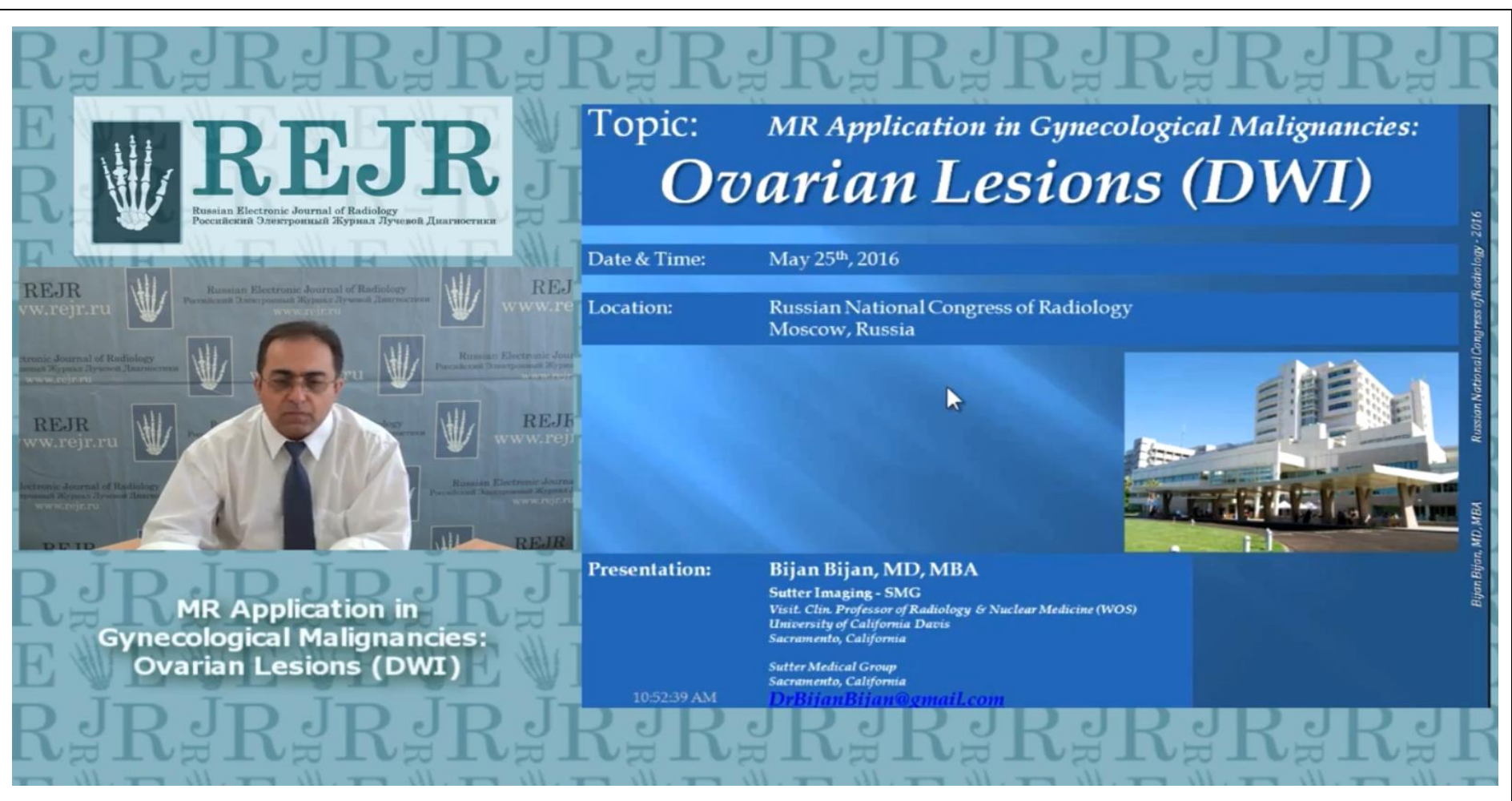

Мастер-кАасс. MR APPLICATION IN GYNECOLOGICAL MALIGNANCIES: OVARIAN LESIONS (DWI).

А^я запуска презентации нажмите на ^юбое место в области презентации, чтобы она загрузилась (если Вы просматриваете журнал в окне браузера, то вначале сохраните журнал к себе на компьютер и откройте его с $А$ кального Аиска, иначе презентация не пойлет).

1) Используйте кнопки влево и вправо в левом нижнем углу страницы Аля перемещения по слайлам.

2) КажАая презентация сопровожАается текстовым или звуковым комментарием автора. ВкАючите в верхнем левом УгАу третью вКАаАКУ - ЗАМЕТКИ. САеАите за текстом автора при перекАючении презентации на новый слайА. ЕсАи презентация сопровожАается звуком, то отрегулируйте уровень звука, нажав на иконку Аинамика.

3) Чтобы вк^ючить полноэкранный просмотр презентации Аостаточно нажать ^евой кнопкой мыши на правую нижнюю кАавишу перехола в полноэкранный режим.

Если у Вас не отображается мастер-класс - установите Adobe Flash Player: http://get.adobe.com/ru/flashplayer/

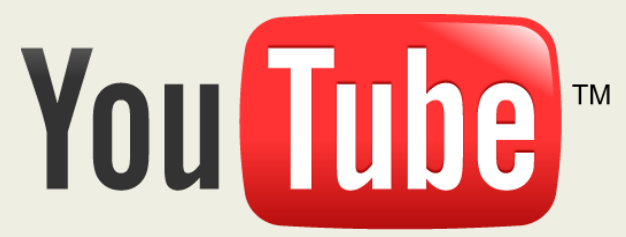

Внимание! Презентация защищена авторскими правами. Полное ияи частичное копирование материала запрещено, без преАварительного согласия авторов. 